\title{
PRODUCTION OF DIRECT SEEDED UNIHOT PEPPER IN SAND SOIL
}

\author{
${ }^{1}$ Péter Tóth Horgosi ${ }^{*},{ }^{2}$ Zoltán Pék \\ ${ }^{1}$ Department of Horticulture, Faculty of Horticulture and Rural Development, John von Neumann \\ University, Hungary \\ ${ }^{2}$ Szent István University, Gödöllö, Hungary \\ https://doi.org/10.47833/2020.2.AGR.034
}

\section{Keywords:}

Unihot

Direct seeding

Capsaicin

ASTA

Yield

\section{Abstract}

The aim of our study was to investigate the production of direct seeded Unihot pepper. In our measurements the following parameters were examined: yield, average berry weight, capsaicin and pigment content. Open field experiments were carried out at Univer Product Plc. in Szentkirály in 2018.

\section{Article history:}

Received 15 May 2020

Revised 20 May 2020

Accepted 25 May 2020

\section{Introduction}

The paprika contributed significantly to the foundation of the reputation of Hungarian cuisine. Its consumption increases the production of digestive juices, thereby improving digestion.

In addition to colouring agents, sugars and essential oils play an important role in the development of the characteristic aroma and taste of paprika.

Its significant role in nutrition is enhanced by its significant vitamin C, E and B content.

Spice peppers are not only used as a spice mill for seasoning, but are also consumed in the form of different paprika preparations.

They are sweet and spicy and contain paprika and occasionally pritamin paprika (Capsicum

annuum var.Lycopersiforme) $[1,4,5]$.

Pepper is an important agricultural crop, not only because of its economic importance, but also for the nutritional value of its fruits, mainly due to the fact that they are an excellent source of natural colours and antioxidant compounds [2].

Carotenoids play an important role in fruit colouring and act as antioxidants, reacting with free radicals, mainly peroxide radicals and singlet molecular oxygen [3] .

The spice paprika in sand soil is usually planted.

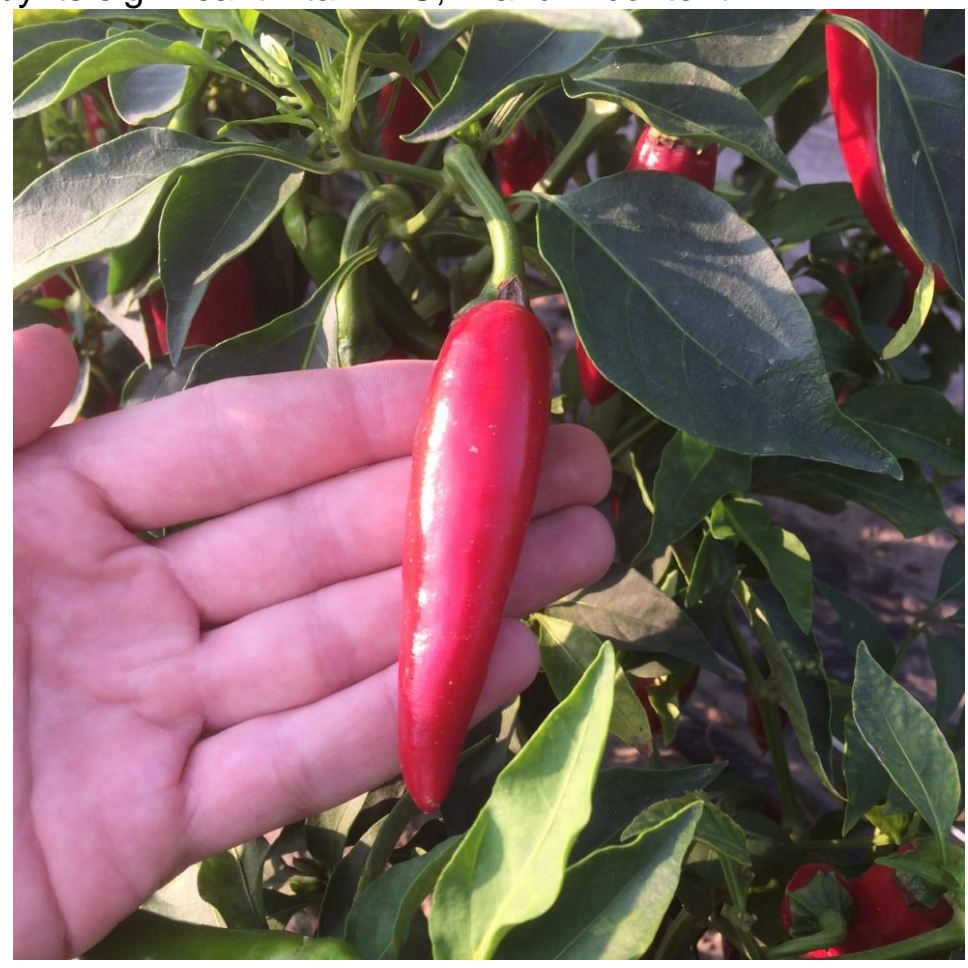

\footnotetext{
* Corresponding author E-mail address: tohopeti@gmail.com
} 
Figure 1: Biologically ripe berrie

\section{Method}

The experiment was direct seeded in April 17, 2018.

The plant density was 400.000 plants/ha. After the direct seeding the soil was regulary irrigated Unihot was harvested in August 29. in 4 replicates. We harvested only the biologically riped berries (Figure 1.) for measuring. A sample weight of $1 \mathrm{~kg}$ was collected from each replicate.

After picking, we counted the number of berries in one kilogram sample (Figure 2.).

After recording all measured datas, the samples were dried in a covered place for 40 days (Figure 3 ). This natural desiccation process drying is a traditional Hungarian method. Before the grinding we used a second drying system. The peppers were dried at seventy degrees Celsius for one day in an industrial dryer (Figure 3).

In our measurements the following parameters were examined: yield, average berry weight, capsaicin, pigment and dry matter content.

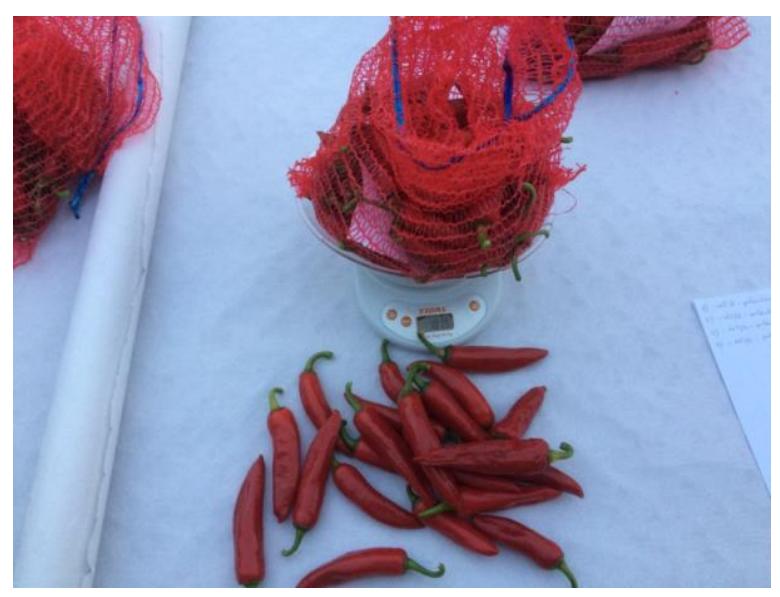

Figure 2: Measuring the fruit

\section{Results}

From our datas it can be stated that Unihot is a reliable variety. In 2018 our yield data was 18, 5 tons / ha.

The average weight of the berries was 8,59 grams.

The capsaicin content of this paprika is $878 \mathrm{mg} /$ $\mathrm{kg}$ required for the hot category.

For pigmment content, at harevest 119 ASTA was measured.

The dry matter content at harvest reached 17, $61 \%$.

Based on the requirements of the processing industry, Unihot belongs to the hot category.

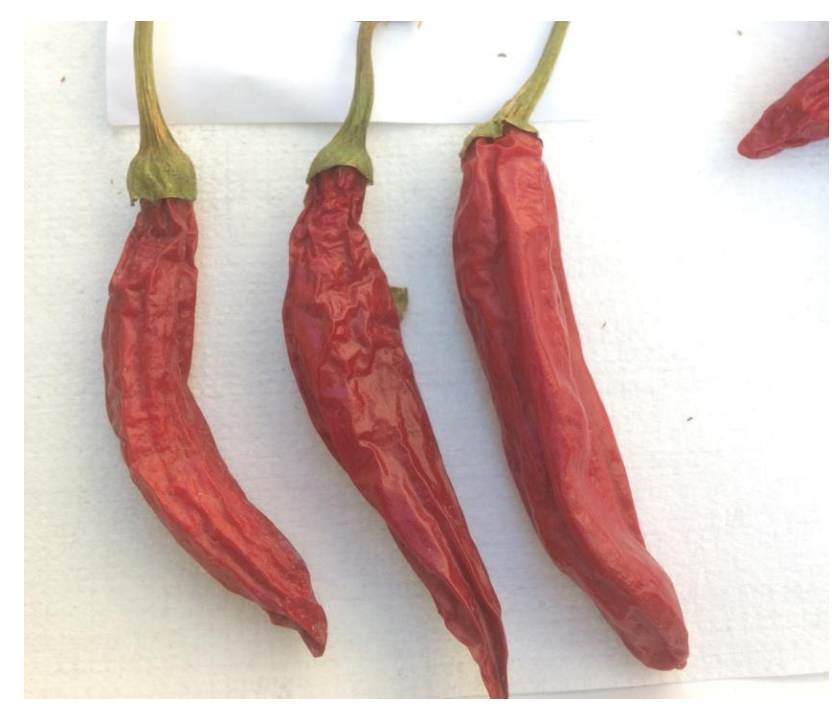

Figure 3: Dried Unihot

\section{Discussion}

From our experiment it can be concluded that the direct seeding method in sand soil is good for industrial use. Despite 2018 was a very unfavorable year, our results show that Unihot can be a perfect raw material for industry.

\section{Acknowledgment}


Thank you for the support of the research carried out in the framework of the EFOP-3.6.2-162017-00012 „Developing a functional, healthy and safe food product chain model from field to table in a thematic research network". The project is funded by the Hungarian State and the European Union, co-financed by the European Social Fund, and is part of the Széchenyi 2020 program

\section{References}

[1] MÁRKUS, F., DAOOD, H. G., KAPITÁNY, J., BIACS, P. A. (1999): Change in the carotenoid and antioxidant content of spice red pepper (paprika) as a function of ripening and some technological factors, Journal of Agricultural and Food Chemistry,47,100-107.p. DOI: http://dx.doi.org/10.1021/if980485z

[2] Koncsek, A., Horváth, Zs. H. Véha, A. Daood, H. G. Helyes, L. (2016): Colour evolution of conventionally and organically cultivated hungarian red spice paprika varieties. Analecta, (Analecta Technica Szegedinensia) 10, (1), pp. 6-15. ISSN: 2064-7964

[3] Duc, N.H., Mayer, Z., Pék, Z., Helyes, L., Posta, K. (2017): Combined inoculation of arbuscular mycorrhizal fungi, Pseudomonas Fluorescens and Trichoderma spp. For enhancing defense enzymes and yield of three pepper cultivars, APPLIED ECOLOGY AND ENVIRONMENTAL RESEARCH 15. (3): pp. 1825-1829. DOI: 10.15666/aeer/1503_18151829 ISSN: 15891623 Koncsek A. Daood G. H. Miklós Nagy Cs. Helyes L. (2015): Konvencionális és ökológiai termesztésből származó füszerpaprika összehasonlító értékelése. Kertgazdaság, 47. (3) pp. 15-24.

[4] Ittah, Y., Kanner, J., Granit, R., 1993. Hydrolysis study of carotenoid pigments of paprika (Capsicum annuum L. variety Lehava) by HPLC/ photodiode array detection. Journal of Agricultural and Food Chemistry 41, 899-901.

[5] Tsuchiya, H., 2001. Biphasic membrane effects of capsaicin, an active component in Capsicum species. Journal of Namiki, M. (1990). Antioxidants/antimutagens in food. CRC Critical Reviews in Food Science and Nutrition, 29, 73300. 